\title{
Electrosynthesis and characterization of copper dicyanamide materials
}

\author{
Phuong Thu Nguyen ${ }^{\text {a, * }}$, Thom Thi Nguyen, Formal analysis ${ }^{a}$, Nam Thi Pham, Formal analysis ${ }^{\text {a }}$ \\ Claudine Buess-Herman ${ }^{\mathrm{b}}$, Hien Thi Le Nguyen, Writing - review \& editing ${ }^{\mathrm{c}}$, Thanh Thi \\ Mai Dinh ${ }^{\text {a,d }}$ \\ ${ }^{a}$ Institute for Tropical Technology, Vietnam Academy of Science and Technology, 18 Hoang Quoc Viet, Cau Giay District, Hanoi 10000, Vietnam \\ ${ }^{\mathrm{b}}$ Chemistry at Surfaces, Interfaces and Nanostructure (ChemSIN), Faculté des Sciences, Université libre de Bruxelles (ULB), Boulevard du Triomphe, 2, CP 255, B-1050 \\ Bruxelles, Belgium \\ ${ }^{\mathrm{c}}$ Center for Technology Application and Transfer, Vietnam Petroleum Institute, 167 Trung Kinh, Yen Hoa, Cau Giay District, Hanoi 10000, Vietnam \\ ${ }^{\mathrm{d}}$ University of Science and Technology of Hanoi, Vietnam Academy of Science and Technology, 18 Hoang Quoc Viet, Cau Giay District, Hanoi 10000, Vietnam
}

\section{A R T I C L E I N F O}

\section{Keywords:}

Copper(I)

copper(II)

dicyanamide

electrosynthesis

adsorption capacity

\begin{abstract}
A B S T R A C T
X-ray diffraction and infrared reflection spectroscopy data have confirmed the electrosynthesis of copper dicyanamide films by cyclic voltammetry and potentiostatic electrolysis. An insoluble $\mathrm{Cu}(\mathrm{I}) \mathrm{dca}$ film can be synthesized on a gold or copper electrode by the reduction of $\mathrm{Cu}(\mathrm{II})$ or oxidation of $\mathrm{Cu}(0)$ in aqueous or methanolic solutions containing dicyanamide ions. By resorting to the use of the ruthenium hexaammine redox probe the $\mathrm{Cu}(\mathrm{I}) \mathrm{dca}$ film was shown to be electronically conductive although the deposition rate decreases when the film formation proceeds.

Depending on the applied potential, not only $\mathrm{Cu}(\mathrm{I})$ dca but also $\mathrm{Cu}(\mathrm{II})$ dca can be formed by oxidation of a copper electrode in presence of dicyanamide ions dissolved in methanol. The powder obtained by electrolysis at $1 \mathrm{~V}$ vs $\mathrm{Hg} / \mathrm{Hg}_{2} \mathrm{SO}_{4}$ made essentially of $\mathrm{Cu}$ (II)dca presents a specific surface area of $(183 \pm 59) \mathrm{m}^{2} / \mathrm{g}$. This material can adsorb preferentially methyl orange and Congo red dyes compared to methylene blue whereas no marked difference is obtained between $\mathrm{CO}$ and $\mathrm{CO}_{2}$ adsorption.
\end{abstract}

\section{Introduction}

In the last decades dicyanamide $\left(\mathrm{N}(\mathrm{CN})_{2}{ }^{-}\right.$or dca) was widely used as a bridge ligand to form complexes with $\mathrm{Cu}, \mathrm{Ni}, \mathrm{Co}, \mathrm{Fe}, \mathrm{Mn}, \mathrm{Pb}$ ions specially in relation with their potential use as molecular magnets [1-5]. It is also of interest to mention that some works have also reported on the inhibition properties of dicyanamide against metal corrosion. Ethyl-3-methylimidazolium dicyanamide (EMI-dca) was investigated against mild steel corrosion [6]. Scanning electron microscope (SEM) analysis and potentiodynamic studies showed that the anionic part of EMI-dca plays the major adsorption role and leads to a better protection efficiency of the coating. Dicyanamide anions have also an influence on the formation of electrodeposits as it was shown in the study of Xie et al. [7]. The use of EMI-dca modified the $\mathrm{Zn}$ deposit morphology by changing the $\mathrm{Zn}$ reduction process and the $\mathrm{Zn}$ film/electrolyte interface.

Owing to the diversity of possible binding modes of the dicyanamide anion, dca is also a building block that is used in the presence of other organic co-ligands especially amines to generate many $\mathrm{Cu}(\mathrm{II})$ [8-13] and
Cu(I) [14] coordination polymers.

Besides their magnetic and electronic properties, metal dicyanamide materials may also act as solid adsorbents since $2 \mathrm{D}$ or $3 \mathrm{D}$ structures with some porosity are reported. Recently hexamethylenetetramine was used as a co-ligand to prepare a Co (II) dicyanamide material that exhibits high $\mathrm{CO}_{2} / \mathrm{N}_{2}$ selectivity [15].

Due to its technological importance, copper is a metal that has attracted researches exploring the use of ionic liquids in electrochemistry. Ionic liquids composed of dca as anion are known to dissolve metals through the formation of complexes [1,2,16-18].

The electrochemical behavior of $\mathrm{Cu}(\mathrm{I})$ and $\mathrm{Cu}(\mathrm{II})$ ions investigated in the presence of 1-butyl-3-methylimidazolium dicyanamide revealed the presence of two redox couples $\mathrm{Cu}(\mathrm{II}) / \mathrm{Cu}(\mathrm{I})$ and $\mathrm{Cu}(\mathrm{I}) / \mathrm{Cu}(0)$ due to the stabilization of $\mathrm{Cu}(\mathrm{I})$ in the presence of dca anions [19]. A contrasted behavior was moreover observed for $\mathrm{Cu}(\mathrm{I})$ and $\mathrm{Cu}(\mathrm{II})$ in contact with a copper deposit. Chronopotentiometry and electrochemical quartz crystal microbalance (EQCM) measurements have evidenced the presence of a comproportionation reaction $\mathrm{Cu}(\mathrm{II})+\mathrm{Cu}(0) \rightarrow 2 \mathrm{Cu}(\mathrm{I})$.

\footnotetext{
* Corresponding author.

E-mail address: ntphuong@itt.vast.vn (P.T. Nguyen).
} 
Following this work, the electrochemical behavior of $\mathrm{Cu}$ (II) ions has also been explored in acidic aqueous solutions in the presence of sodium dicyanamide by Rayée et al. [20]. Two consecutive one electron transfer processes were also observed. However, the behavior in aqueous solutions is more complex since an insoluble film was formed at the electrode surface after the reduction of $\mathrm{Cu}$ (II) to $\mathrm{Cu}$ (I).

Olaf Reckeweg et al. [21] synthesized the air and water stable copper (I) dicyanamide. $\mathrm{Cu}(\mathrm{I}) \mathrm{dca}$ as well as $\mathrm{Cu}(\mathrm{II})$ dca were obtained by a chemical method and characterized by different methods (X-ray diffraction (XRD), Infrared (IR), Thermal gravimetric analysis (TGA), Differential scanning calorimetry (DSC)). Cu(dca) (as almost colorless platelets) was formed by a reaction between an aqueous $\mathrm{Cu}^{+}$solution (obtained by dissolving $\mathrm{Cu}\left[\mathrm{NO}_{3}\right]_{2} \cdot 2 \cdot 5 \mathrm{H}_{2} \mathrm{O}$ and an excess of $\mathrm{K}_{2} \mathrm{~S}_{2} \mathrm{O}_{5}$ ) with a stoichiometric amount of Nadca. By mixing stoichiometric amounts of aqueous $\mathrm{Cu}\left(\mathrm{NO}_{3}\right)_{2} .2 .5 \mathrm{H}_{2} \mathrm{O}$ and Nadca, $\mathrm{Cu}$ (dca) $)_{2}$ (green powder) was synthesized. Cudca crystallizes in the orthorhombic space group with the lattice parameters $a=356.28(3), b=611.10(9)$ and $c=1525.87$ (10) pm. The atomic coordinates and selected bond distances and angles were extracted from the experimental data. The $\mathrm{Cu}^{+}$ion is predominantly coordinated in a linear way by two terminal nitrogen atoms of two different dca anions. Vibrational information given by the IR and Raman spectra are also provided by the authors.

Previous work performed by Rayée et al. has shown that the dicyanamide anion (dca) can complex cuprous ions electrogenerated [22]. Various parameters of the electrolysis performed in acid solutions and more particularly the applied potential, electrolysis time as well as the Nadca concentration have been explored. These results have motivated us to perform additional work to synthesize and characterize the electrochemical behavior of Cudca deposited films and to examine the dye and gas adsorption abilities of the electrosynthesized $\mathrm{Cu}(\mathrm{II}) \mathrm{dca}$ powders.

\section{Materials and methods}

2.1. Reagents. Copper (II) nitrate hemi(pentahydrate) (Sigma, 98\%), copper sulfate pentahydrate (Merck, analytical grade), sodium dicyanamide (Sigma, 96\%), Potassium disulfite (Sigma, 98\%), hexaammineruthenium (III) chloride (Sigma, 98\%), sulphuric acid (Merck, 96\%), phosphoric acid (ChemLab, analytical grade), potassium bromide (Merck, analytical grade), methylene blue (Acros organics, 96\%), methyl orange (Merck, analytical grade) and Congo red (Merck, analytical grade) were used as received. Sodium nitrate (Merck, 99.5\%) was used as an electrolyte. Solutions were prepared with ultrapure water (Milli-Q system from Millipore) or methanol (VWR Prolabo 99.9\%). Nitrogen (Air Liquide, > 99.99\%) was used to purge the solutions. Ar, $10 \% \mathrm{CO} / \mathrm{He}, 5 \% \mathrm{CO}_{2} / \mathrm{Ar}$, (Praxair, 99.95\%) were used for gas adsorption experiments.

\subsection{Method of Cudca synthesis}

\subsubsection{Synthesis $\mathrm{Cu}(I) d c a$ and $\mathrm{Cu}(\mathrm{II}) d \mathrm{ca}$ by the chemical method}

$\mathrm{Cu}(\mathrm{I}) \mathrm{dca}$ (colorless thin platelets) was synthesized by the reaction between $\mathrm{Cu}^{+}$solution (formed by the dissolution of $\mathrm{Cu}\left(\mathrm{NO}_{3}\right)_{2} \cdot 2 \cdot 5 \mathrm{H}_{2} \mathrm{O}$ and $\mathrm{K}_{2} \mathrm{~S}_{2} \mathrm{O}_{5}$ ) with a stoichiometric amount of Nadca. The precipitation was filtered and washed by ethanol and dried. By mixing a stoichiometric amount of $\mathrm{Cu}\left(\mathrm{NO}_{3}\right)_{2} \cdot 2 \cdot 5 \mathrm{H}_{2} \mathrm{O}$ and Nadca, $\mathrm{Cu}(\mathrm{dca})_{2}$ (green powder) was synthesized.

\subsubsection{Synthesis $\mathrm{Cu}(\mathrm{I}) \mathrm{dca}$ by the reduction of $\mathrm{Cu}(\mathrm{II})$}

$\mathrm{Cu}(\mathrm{I}) \mathrm{dca}$ was synthesized on gold plate (Arrandee GMBH). The gold plates were rinsed with water, acetone (to remove oil and grease), water and dried by $\mathrm{N}_{2}$ gas, before being introduced in a flame as a final cleaning of the surface. An Autolab PGSTAT30 potentiostat (Metrohm) was used for all electro-chemical experiments. The gold plate is the working electrode, the $\mathrm{Hg} / \mathrm{Hg}_{2} \mathrm{SO}_{4}$ electrode is the reference electrode, the counter electrode is a platinum gauze. The solution containing $0.1 \mathrm{M}$ $\mathrm{H}_{2} \mathrm{SO}_{4}+\mathrm{CuSO}_{4}(1 \mathrm{mM}$ and $5 \mathrm{mM})+100 \mathrm{mM} \mathrm{dca}{ }^{-}$. The applied potential is $-0.13 \mathrm{~V} ;-0.21 \mathrm{~V}$ and $-0.4 \mathrm{~V}$ vs $\mathrm{Hg} / \mathrm{Hg}_{2} \mathrm{SO}_{4}$ during $240 \mathrm{~s}$. The obtained film was rinsed with water and dried by $\mathrm{N}_{2}$ gas.

\subsubsection{Synthesis Cudca by the oxidation of $\mathrm{Cu}(0)$}

The electrochemical experiments were conducted in a 3-electrode cell including a mercury sulfate $\mathrm{Hg} \mid \mathrm{Hg}_{2} \mathrm{SO}_{4}$ reference electrode, a platinum gauze counter electrode and a copper plate working electrode (99.9\%). The working electrode was electropolished in $60 \% \mathrm{H}_{3} \mathrm{PO}_{4}$ for $10 \mathrm{~min}$. A potential of $1.7 \mathrm{~V}$ was applied between a round copper plate and the $\mathrm{Cu}$ working electrode acting respectively as cathode and anode. Then, the electropolished copper electrode was rinsed using $10 \% \mathrm{H}_{3} \mathrm{PO}_{4}$ and distilled water. Autolab PGSTAT30 potentiostat (Metrohm) and Biologic VSP-300 were used for electrochemical experiments.

In aqueous solution: The solution containing $0.1 \mathrm{M} \mathrm{H}_{2} \mathrm{SO}_{4}+\mathrm{Nadca}$ with different concentration $(0.01 \mathrm{M}, 0.05 \mathrm{M}$ and $0.1 \mathrm{M})$. In methanolic solution: The synthesis solution consists of: methanol $+0.05 \mathrm{M} \mathrm{NaNO}_{3}$ $+0.05 \mathrm{M}$ Nadca. After applying a potential of $1 \mathrm{~V}$ to obtain a charge of $100 \mathrm{C} / \mathrm{cm}^{2}$, the powder was filtered and rinsed three times by methanol, dried at $80{ }^{\circ} \mathrm{C}$ overnight and milled for further analysis and adsorption experiments.

\subsection{Characterization}

Infrared spectra were recorded by a Nicolet iS10 spectrometer (Thermo Scientific) with 128 scans at a resolution of $2 \mathrm{~cm}^{-1}$ using $\mathrm{KBr}$ pellet technique. The morphology of the material was examined by scanning electron microscopy using a Jeol SM-6510LV SEM microscope with $5 \mathrm{kV}$ operating voltage. The phase component of the obtained material was performed with a X-ray diffractometer D8 Advance Bruker using a $\mathrm{Cu}$ anode, $\lambda=0.154056 \mathrm{~nm}$. The specific surface area of $\mathrm{Cu}$ (II) dca was determined by a Micromeristics ASAP 2020 equipment with the Brunauer-Emmett-Teller method based on $\mathrm{N}_{2}$ adsorption. The thermal stability of $\mathrm{Cu}(\mathrm{II}) \mathrm{dca}$ was analyzed by Thermal gravimetric analysis using a Pyris 6 TGA equipment with the heating rate of $5{ }^{\circ} \mathrm{C} /$ minutes. The estimated thickness of the film of about $300 \pm 100 \mathrm{~nm}$ was determined by a Bruker DektakXT profilometer.

\subsection{Dye adsorption experiments}

$\mathrm{Cu}(\mathrm{II}) \mathrm{dca}$ powders were used to evaluate the adsorption capacity of three dyes (methylene blue, methyl orange and Congo red) with the following procedure: $2 \mathrm{mg}$ of powder were added in $7.5 \mathrm{~mL}$ of $10 \mathrm{mg} / \mathrm{L}$ methylene blue, methyl orange or Congo red aqueous solutions and stirred during different times in ambient conditions. After a defined time, the mixture was centrifuged to separate the solution from the powder. The absorbance of initial solution $\mathrm{A}_{\text {init }}$ and of the recovered solution $\mathrm{A}_{\text {recov }}$ were measured by an UV-3100 PC VWR spectrometer in the visible range. The yield $\mathrm{H}$ and the adsorption capacity $\mathrm{Q}$ are calculated according to:

$H=\left(A_{\text {init }}-A_{\text {recov }}\right) / A_{\text {init }} * 100 \%$

$Q=\left(C_{\text {int }}-C_{\text {recov }}\right) * V / m$

with $\mathrm{C}_{\text {int }}$ and $\mathrm{C}_{\text {recov }}$ the dye concentration before and after contact with the adsorbent, $\mathrm{V}$ the volume of solution and $\mathrm{m}$ the mass of adsorbent.

\subsection{Gas adsorption measurements}

Cudca powders (with size in the range 150-250 $\mu \mathrm{m}$ ) were heated overnight in the oven at $80^{\circ} \mathrm{C}$ to remove water in the sample. After that, a sample mass (about $20 \mathrm{mg}$ ) was placed in the reactor. The blank used is SiC. The Diffuse Reflectance Infrared Fourier Transform Spectroscopy (DRIFTS) / Mass Spectrometry experimental set-up consists of a high temperature diffuse reflectance infrared cell (from Spectra-Tech) allowing sample preconditioning as well as reaction and infrared 


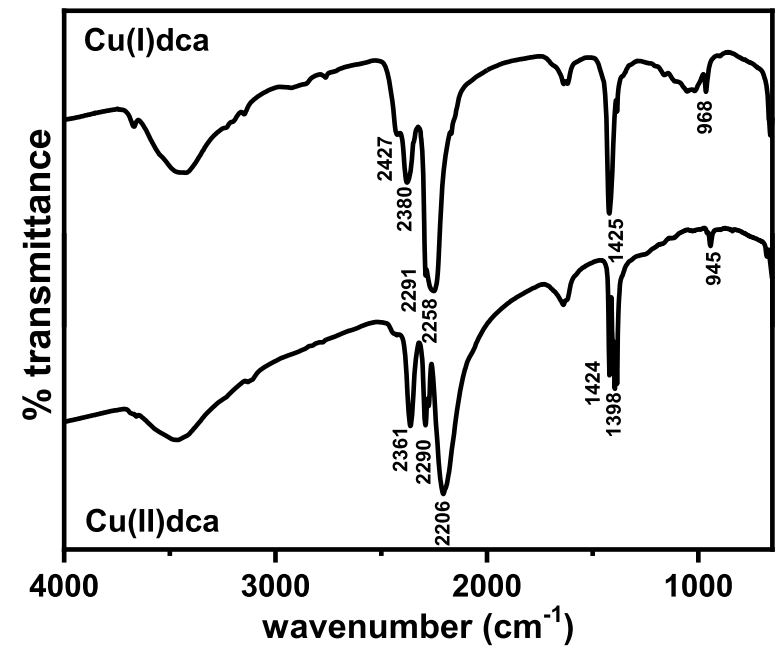

Fig. 1. IR spectra of $\mathrm{Cu}(\mathrm{I}) \mathrm{dca}$ and $\mathrm{Cu}(\mathrm{II})$ dca formed by the chemical method.

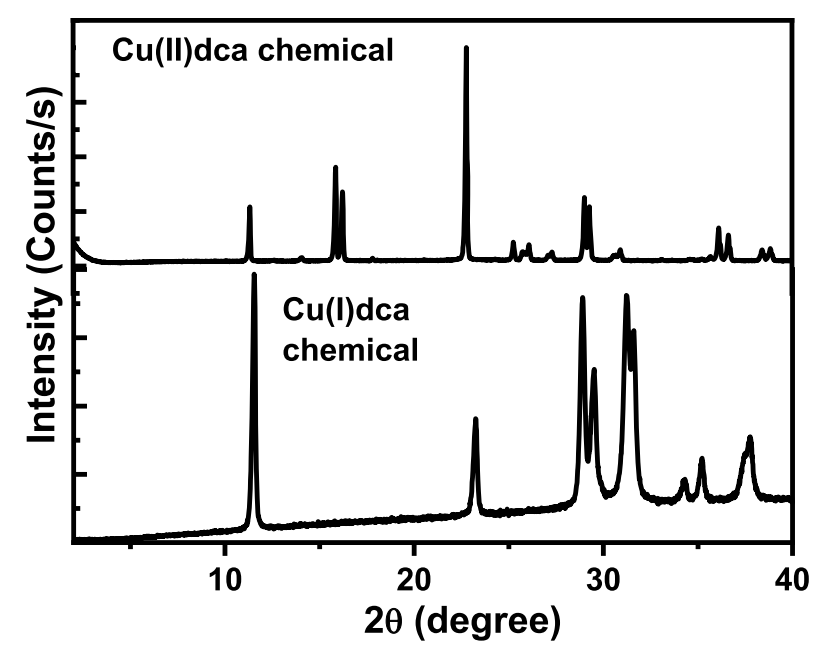

Fig. 2. Experimental diffractogram of $\mathrm{Cu}(\mathrm{I}) \mathrm{dca}$ and $\mathrm{Cu}(\mathrm{II}) \mathrm{dca}$ formed by the chemical method.

studies at variable temperatures (without moving the sample). The DRIFTS cell used as a reactor is located in a Bruker Vertex 70 spectrometer.

The DRIFTS cell is fitted with ZnSe windows and has been modified to prevent any sample by-pass for the gasses. The DRIFTS cell is connected to the feed gas cylinders through $1 / 8^{\prime \prime}$ stainless steel pipes. Gas flows are adjusted by Aera mass flow controllers. The valves are used to introduce the gasses at a controlled $20 \mathrm{~mL} / \mathrm{min}$ flow. The outlet gas composition of the DRIFTS cell is analyzed by a Hiden Analytical QGA (Quantitative gas analyzer) equipment. The purity of all gasses (i.e. Ar, $10 \% \mathrm{CO} / \mathrm{He}, 5 \% \mathrm{CO}_{2} / \mathrm{Ar}$ ) is $>99.95 \%$. All gasses have been supplied by Praxair. The experimental procedure is summarized below:

- Ar is flowed at $20 \mathrm{~mL} / \mathrm{min}$ at $80^{\circ} \mathrm{C}$.

- The temperature is decreased to $25^{\circ} \mathrm{C}$ for $30 \mathrm{~min}$.

- The reactive gasses are flowed for 1 hour at a rate of $20 \mathrm{~mL} / \mathrm{min}$. The gasses are $10 \% \mathrm{CO}$ in $\mathrm{He}$, and $5 \% \mathrm{CO}_{2}$ in $\mathrm{Ar}$.

- Ar is flowed during $30 \mathrm{~min}$ at $20 \mathrm{~mL} / \mathrm{min}$.

The partial pressure $\mathrm{p}_{i}$ of species $\mathrm{i}$ in the outlet gas is obtained from the signal or peak current $I_{i}$ of the mass spectrometer. Therefore, sensitivity coefficients $S_{i}=I_{i}(t) / p_{i}(t)$ are determined by calibration by measuring signals for different gas ratios.

The difference between the molecular flow rate of $\mathrm{CO}_{2}$ or $\mathrm{CO}$ as a function of time for the sample $\mathrm{Cu}(\mathrm{II}) \mathrm{dca}$ and the blank SiC provides the adsorbed quantity of $\mathrm{CO}_{2}$ or $\mathrm{CO}$.

\section{Results and discussion}

\subsection{Synthesis of Cudca by a chemical method}

To facilitate the interpretation of the IR and X-ray measurements performed on the electrodeposited material, $\mathrm{Cu}(\mathrm{I}) \mathrm{dca}$ and $\mathrm{Cu}(\mathrm{II}) \mathrm{dca}$ were synthesized by a chemical method following the procedure described by Reckeweg et al. [21]. The Cu(I)dca compound was formed from Nadca and $\mathrm{Cu}^{+}$that was obtained by the reaction of $\mathrm{Cu}\left(\mathrm{NO}_{3}\right)_{2}$ with $\mathrm{K}_{2} \mathrm{~S}_{2} \mathrm{O}_{5}$ in excess. $\mathrm{Cu}(\mathrm{II})$ dca was synthesized directly from $\mathrm{Cu}\left(\mathrm{NO}_{3}\right)_{2}$ and Nadca. Fig. 1 and Fig. 2 present respectively the IR spectra and X-ray diffraction patterns of $\mathrm{Cu}(\mathrm{I}) \mathrm{dca}$ and $\mathrm{Cu}(\mathrm{II}) \mathrm{dca}$ synthesized by the chemical method. These data are in very good agreement with the results published by Reckeweg et al. [21].

Fig. 3 presents SEM images of $\mathrm{Cu}(\mathrm{I})$ dca synthesized by the chemical method. $\mathrm{Cu}(\mathrm{I}) \mathrm{dca}$ presents a plate shape sizing about $0.25 \mu \mathrm{m}$ to $1.5 \mu \mathrm{m}$.

\subsection{Electrosynthesis of the cudca at a gold electrode}

In previous research [22], we reported cyclic voltammograms recorded at an $\mathrm{Au}$ electrode in a solution containing $0.1 \mathrm{M} \mathrm{H}_{2} \mathrm{SO}_{4}$ with various $\mathrm{CuSO}_{4}$ and sodium dicyanamide concentrations. Two consecutive one electron transfer processes were observed indicating that $\mathrm{Cu}(\mathrm{I})$
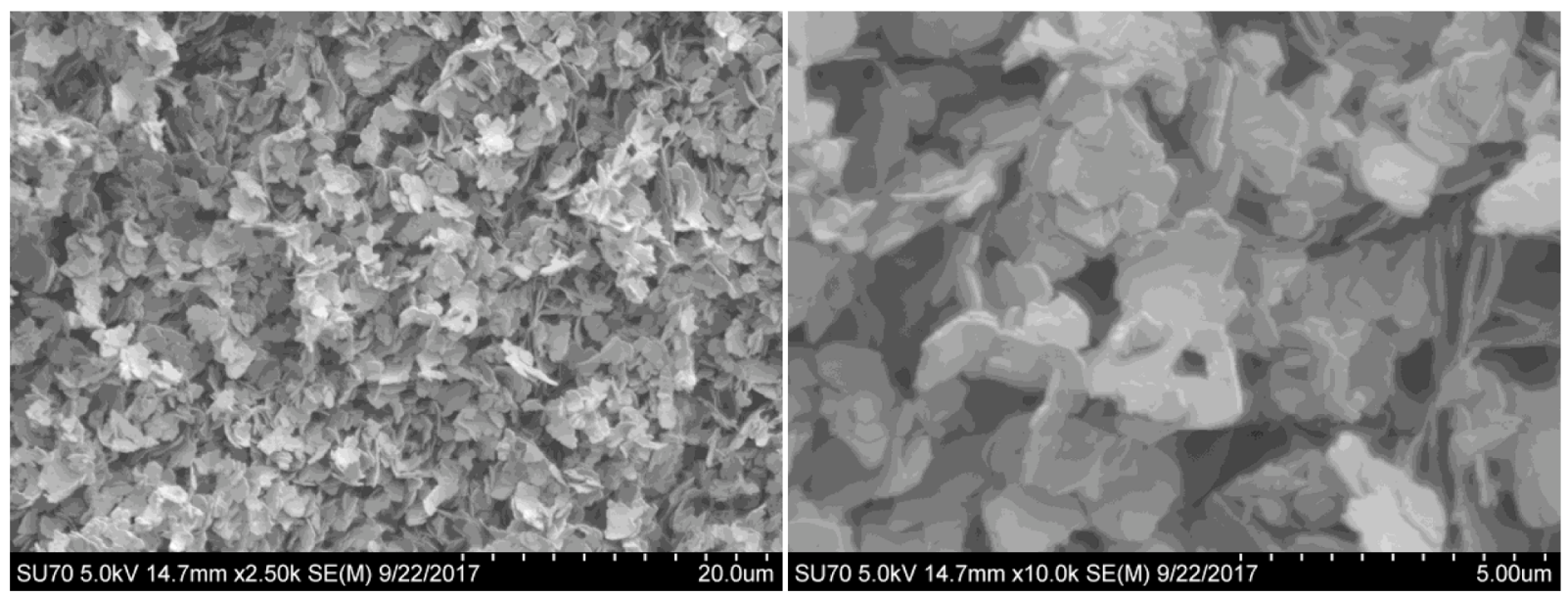

Fig. 3. Scanning electron microscopy images of a $\mathrm{Cu}(\mathrm{I})$ dca powder formed by the chemical method. 


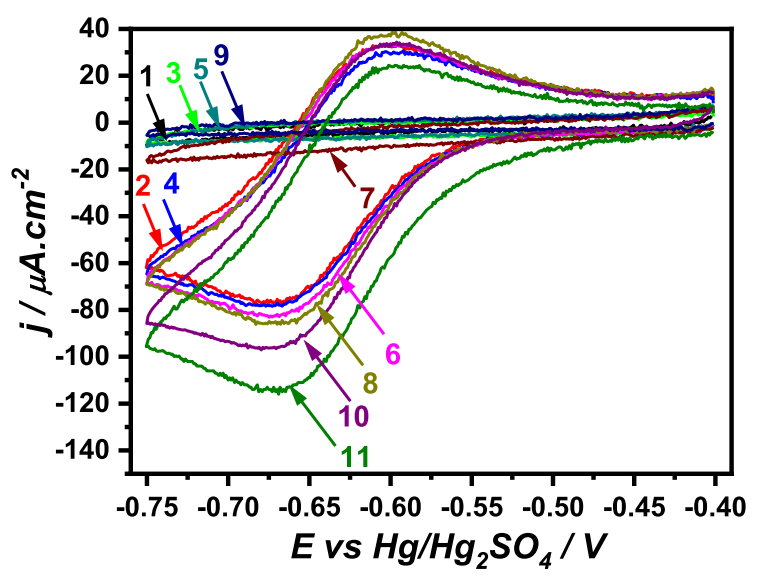

Fig. 4. Cyclic voltammograms of the films synthesized at different $\mathrm{CuSO}_{4}$ concentrations (5 mM (1-6), $1 \mathrm{mM}(7-10)$ ) in presence of $100 \mathrm{mM}$ Nadca and different potentials.

is stabilized by the dicyanamide anion at the electrode surface. The formation of an insoluble film after reduction of $\mathrm{Cu}(\mathrm{II})$ to $\mathrm{Cu}$ (I) was evidenced by EQCM measurements and imaged by scanning electron microscopy. XRD and infrared reflection spectroscopy data have confirmed the formation of a $\mathrm{Cu}(\mathrm{I}) \mathrm{dca}$ film. High concentrations of the precursors are generally used in order to increase the amount of material synthesized but this trend was not observed here. The electrochemical data revealed that at high $\mathrm{Cu}(\mathrm{II})$ concentrations, the deposition current decreases rapidly and monotonously to zero. These results have motivated us to perform additional work to characterize the electrochemical behavior of the deposited films.

Films synthesized with different $\mathrm{CuSO}_{4}$ concentrations and at different potentials on a polycrystalline Au electrode in contact with $100 \mathrm{mM}$ Nadca were characterized by cyclic voltammetry in pure $0.1 \mathrm{M}$ $\mathrm{H}_{2} \mathrm{SO}_{4}$ and in $0.1 \mathrm{M} \mathrm{H}_{2} \mathrm{SO}_{4}+10^{-3} \mathrm{M} \mathrm{Ru}\left(\mathrm{NH}_{3}\right)_{6} \mathrm{Cl}_{3}$ used as redox probe (Fig. 4).

(Legends: 1) $5 \mathrm{mM}-0.13 \mathrm{~V}$ in $\mathrm{H}_{2} \mathrm{SO}_{4}$; 2) $5 \mathrm{mM}-0.13 \mathrm{~V}$ in $\mathrm{H}_{2} \mathrm{SO}_{4}+$

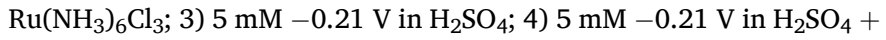
$\mathrm{Ru}\left(\mathrm{NH}_{3}\right)_{6} \mathrm{Cl}_{3}$; 5) $5 \mathrm{mM}-0.4 \mathrm{~V}$ in $\mathrm{H}_{2} \mathrm{SO}_{4}$; 6$) 5 \mathrm{mM}-0.4 \mathrm{~V}$ in $\mathrm{H}_{2} \mathrm{SO}_{4}+\mathrm{Ru}$ $\left(\mathrm{NH}_{3}\right)_{6} \mathrm{Cl}_{3}$; 7) $1 \mathrm{mM}-0.21 \mathrm{~V}$ in $\mathrm{H}_{2} \mathrm{SO}_{4}$; 8) $1 \mathrm{mM}-0.21 \mathrm{~V}$ in $\mathrm{H}_{2} \mathrm{SO}_{4}+\mathrm{Ru}$

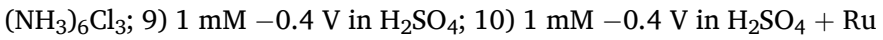
$\left.\left(\mathrm{NH}_{3}\right)_{6} \mathrm{Cl}_{3} ; 11\right) \mathrm{Au}$ in $\left.\mathrm{H}_{2} \mathrm{SO}_{4}+\mathrm{Ru}\left(\mathrm{NH}_{3}\right)_{6} \mathrm{Cl}_{3}\right)$

The curves $1,3,5,7,9$ on Fig. 4 show the cyclic voltammograms in $\mathrm{H}_{2} \mathrm{SO}_{4} 0.1 \mathrm{M}$ for films synthesized with different conditions. The small current densities that are observed indicate that the films are electrochemically stable since no redox process is observed in the potential window explored ( $-0.4 \mathrm{~V}$ vs $\mathrm{Hg} / \mathrm{Hg}_{2} \mathrm{SO}_{4}$ to $-0.75 \mathrm{~V}$ vs $\mathrm{Hg} / \mathrm{Hg}_{2} \mathrm{SO}_{4}$ ). The small negative currents that are measured during the positive sweep are due the presence of some interfering faradaic processes like the reduction of oxygen.

When $\mathrm{Ru}\left(\mathrm{NH}_{3}\right)_{6} \mathrm{Cl}_{3}$ is added to the $\mathrm{H}_{2} \mathrm{SO}_{4} 0.1 \mathrm{M}$ solution in contact with a bare $\mathrm{Au}$ electrode, a typical voltammetric curve is observed (curve 11 on Fig. 4) with two main peaks corresponding respectively to a reduction $\left(\sim-0.665 \mathrm{~V}: \mathrm{Ru}^{3+}+1 e^{-} \rightarrow \mathrm{Ru}^{2+}\right)$ and an oxidation $(\sim$ $\left.-0.606 \mathrm{~V}: \mathrm{Ru}^{2+} \rightarrow \mathrm{Ru}^{3+}+1 e^{-}\right)$process involving 1 electron transfer. The couple $\mathrm{Ru}^{3+} / \mathrm{Ru}^{2+}$ appears as a reversible couple because the potential between the oxidation peak and the reduction peak is $59 \mathrm{mV} / \mathrm{n}_{\mathrm{e}^{-}}$.

A similar shape is observed when the gold surface is modified by the electrodeposited Cudca films (curves 2, 4, 6, 8, 10). This result indicates that the Cudca films do not suppress the electrode activity for the $\mathrm{Ru}^{3+}$ / $\mathrm{Ru}^{2+}$ couple, so that they can be considered as conductive films since transfer of electrons is still possible. The film is still electronically conducting but inhibits ion transport which has shown in Ref. 22 and proved by the results in 3.3 part. Indeed, the Ru system implies only the transfer of an electron (electron transfer reaction) while the formation of

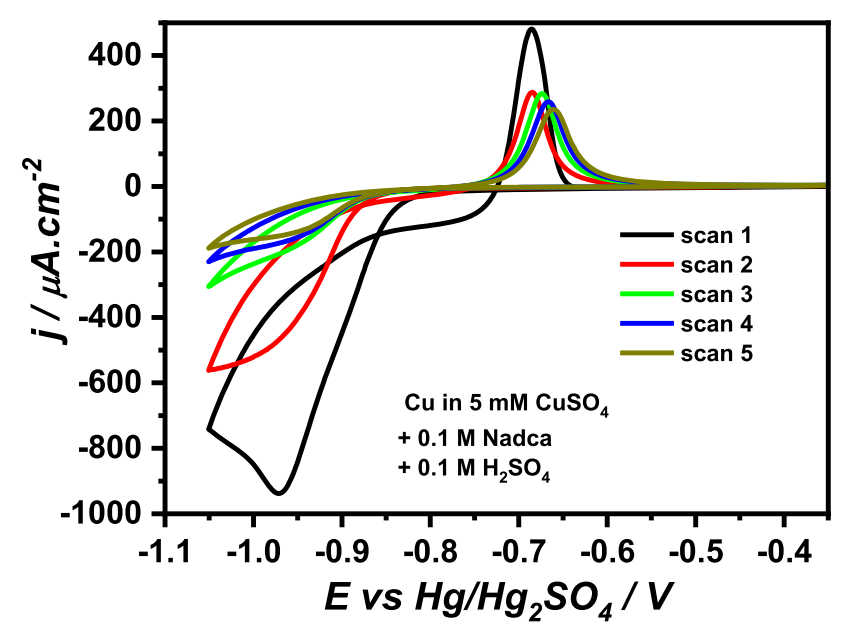

Fig. 5. Cyclic voltammograms of copper electrode in $5 \mathrm{mM} \mathrm{CuSO}_{4}+0.1 \mathrm{M}$ Nadca $+0.1 \mathrm{M} \mathrm{H}_{2} \mathrm{SO}_{4}$ from OCP $\left(-0.35 \mathrm{~V}\right.$ vs $\left.\mathrm{Hg} / \mathrm{Hg}_{2} \mathrm{SO}_{4}\right)$ to $-1.05 \mathrm{~V}$ vs $\mathrm{Hg} / \mathrm{Hg}_{2} \mathrm{SO}_{4}$.

$\mathrm{Cu}(\mathrm{I}) \mathrm{dca}$ is an ion transfer reaction requiring the transfer of copper ions through the film.

\subsection{Electrosynthesis of Cudca compounds at a copper electrode}

$\mathrm{Cu}(\mathrm{I}) \mathrm{dca}$ is expected to be produced electrochemically by two different paths: either by reduction of $\mathrm{Cu}(\mathrm{II})$ to $\mathrm{Cu}(\mathrm{I})$, or by oxidation of $\mathrm{Cu}(0)$ to $\mathrm{Cu}(\mathrm{I})$, in both cases in the presence of dicyanamide in solution. The formation of a Cudca film was indeed also triggered through the oxidation of a copper plate in presence of dicyanamide.

Fig. 5 shows the cyclic voltammetric curves obtained in the presence of a solution containing $5 \mathrm{mM} \mathrm{CuSO}_{4}, 0.1 \mathrm{M} \mathrm{Nadca}$ and $0.1 \mathrm{M} \mathrm{H}_{2} \mathrm{SO}_{4}$, when the potential is scanned several times till $-1.05 \mathrm{~V}$ vs $\mathrm{Hg} / \mathrm{Hg}_{2} \mathrm{SO}_{4}$.

In the region of the peak at $-0.69 \mathrm{~V}$ vs $\mathrm{Hg} / \mathrm{Hg}_{2} \mathrm{SO}_{4}, \mathrm{Cu}(0)$ obtained by reduction during the negative scan is reoxidized to $\mathrm{Cu}(\mathrm{I})$ that reacts with dca anions to form the insoluble compound Cudca at the electrode surface. Subsequent scans reveal that the film remains at the surface and hinders the reduction of $\mathrm{Cu}^{2+}$ ions.

The Cudca film formed in acidic medium shows that dca can be considered as a corrosion inhibitor for copper. The inhibition properties of dicyanamide was also recently recognized for mild steel and zinc [6, 7].

Fig. 6 presents the voltammetric curves obtained at a copper electrode between $-0.8 \mathrm{~V}$ vs $\mathrm{Hg} / \mathrm{Hg}_{2} \mathrm{SO}_{4}$ and $-0.3 \mathrm{~V}$ vs $\mathrm{Hg} / \mathrm{Hg}_{2} \mathrm{SO}_{4}$ in presence of $0.1 \mathrm{M}$ Nadca added to the $0.1 \mathrm{M} \mathrm{H}_{2} \mathrm{SO}_{4}$ electrolyte. During the first scan, we observe a marked peak at $-0.65 \mathrm{~V}$ vs $\mathrm{Hg} / \mathrm{Hg}_{2} \mathrm{SO}_{4}$ associated to the reaction $\mathrm{Cu} \rightarrow \mathrm{Cu}^{+}+e^{-}$leading to the film formation $\left(\mathrm{Cu}^{+}+\mathrm{dca}^{-} \rightarrow\right.$ Cudca). During the second scan, the current density is much lower, and goes nearly to zero in subsequent scans. The same feature is observed in the presence of lower Nadca concentrations (Fig. 7) but the decrease in current happens after a longer time indicating that the passivation occurs when the film is sufficiently thick. We have also tried to synthesize the film by applying $-0.6 \mathrm{~V}$ vs $\mathrm{Hg} / \mathrm{Hg}_{2} \mathrm{SO}_{4}$ for $10 \mathrm{~min}$ in presence of $0.1 \mathrm{M}$ Nadca in $0.1 \mathrm{M} \mathrm{H}_{2} \mathrm{SO}_{4}$. The current density decreases rapidly to a very low value leading to a small charge after $10 \mathrm{~min}\left(4.8 \mathrm{mC} / \mathrm{cm}^{2}\right)$ confirming that thick films cannot be formed.

This fact shows that the film can prevent the copper surface from further oxidation and thus can act as a corrosion protective film for $\mathrm{Cu}$. This also means that only thin films can be obtained similar to what is observed when the film is formed from the reduction of $\mathrm{Cu}(\mathrm{II})$ ions.

The Cudca film formed in acidic medium shows that dca can be considered as a corrosion inhibitor for copper. The inhibition properties of dicyanamide wera also recently recognized for mild steel and zinc [6, 7]. 

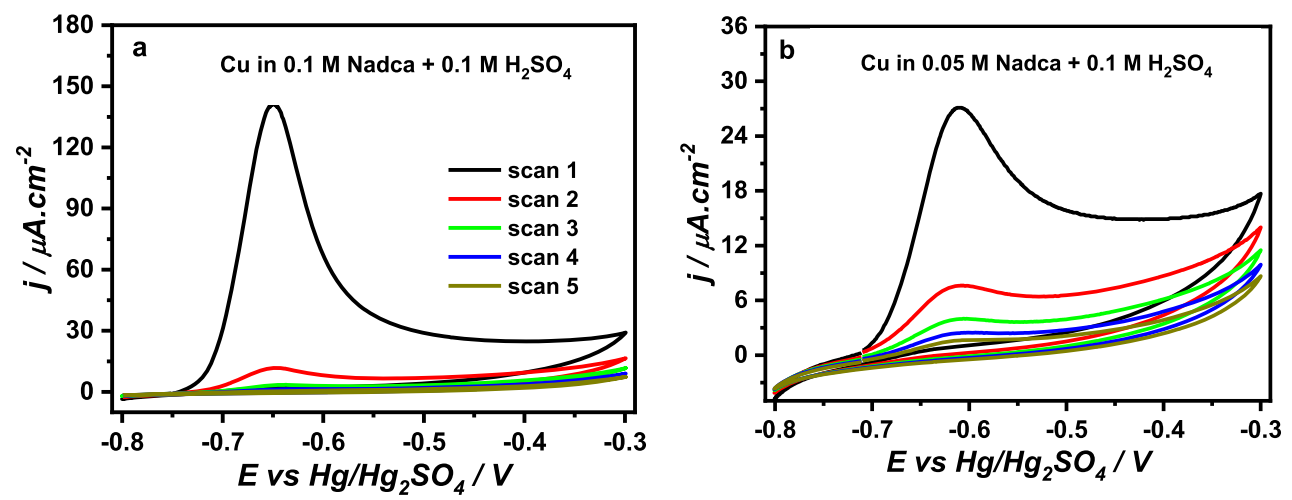

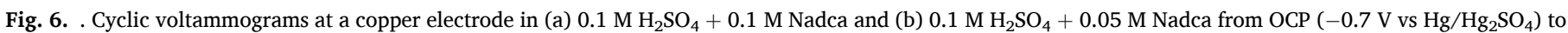
$-0.3 \mathrm{~V}$ vs $\mathrm{Hg} / \mathrm{Hg}_{2} \mathrm{SO}_{4}$ and come back to $-0.8 \mathrm{~V}$ vs $\mathrm{Hg} / \mathrm{Hg}_{2} \mathrm{SO}_{4}$.
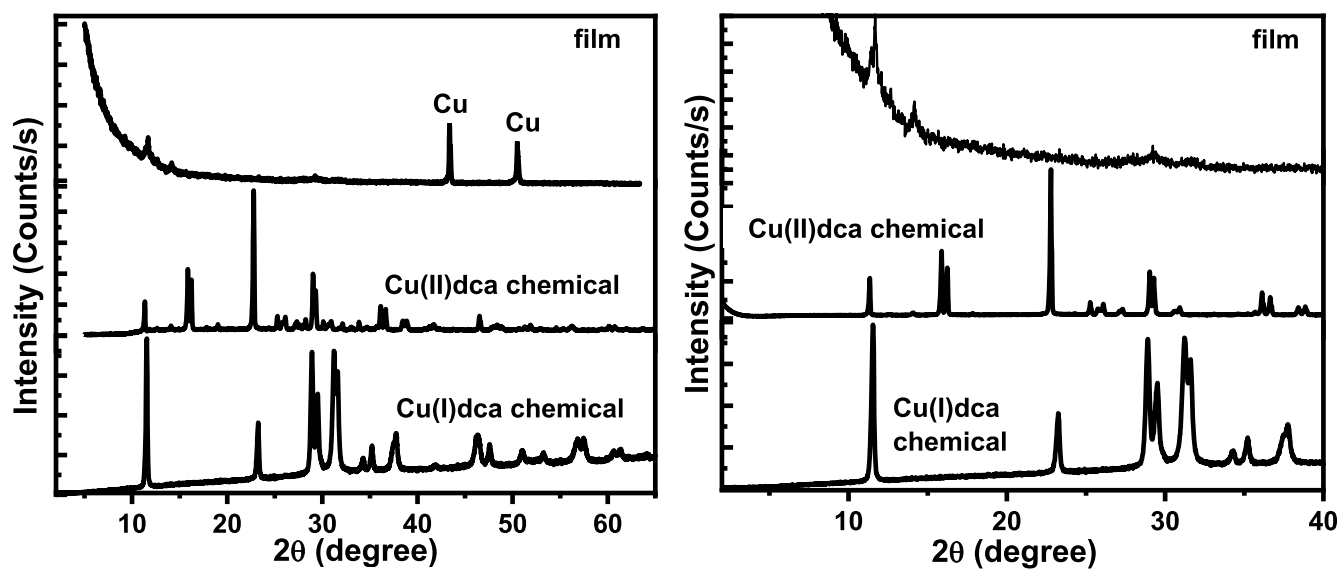

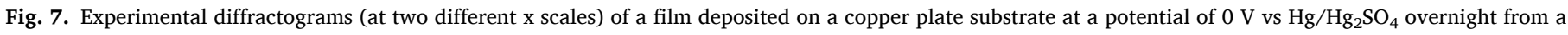
$0.05 \mathrm{M} \mathrm{NaNO}_{3}+0.05 \mathrm{M}$ Nadca methanolic solution compared with $\mathrm{Cu}(\mathrm{I}) \mathrm{dca}$ and $\mathrm{Cu}(\mathrm{II}) \mathrm{dca}$ synthesized by chemical method.

A procedure where the metal cations are generated by the oxidation of the metal electrode while the organic compound is dissolved in solution is often used in electrochemical synthesis of Metal Organic Frameworks. In that case the synthesis often takes place in organic solvents. With the idea to incorporate dca anions as a co-ligand in future electrochemical syntheses, the oxidation of copper was also performed in methanolic solutions containing $0.05 \mathrm{M} \mathrm{NaNO}_{3}$ and $0.05 \mathrm{M}$ Nadca.

$\mathrm{X}$-ray diffraction measurements made on the film synthesized at $0 \mathrm{~V}$ vs $\mathrm{Hg} / \mathrm{Hg}_{2} \mathrm{SO}_{4}$ overnight in air are shown in Fig. 7. The comparison with the data for $\mathrm{Cu}(\mathrm{I}) \mathrm{dca}$ and $\mathrm{Cu}(\mathrm{II}) \mathrm{dca}$ synthesized by the chemical method [21], indicates that the material is a mixture of compounds: $\mathrm{Cu}(\mathrm{I}) \mathrm{dca}$ with characteristic peaks at $11.7^{\circ}$ and around $30^{\circ}$ and $\mathrm{Cu}(\mathrm{II}) \mathrm{dca}$ with characteristic peak at $14.1^{\circ}$. The presence of a mixed composition can be explained as follows: at $0 \mathrm{~V}$ vs $\mathrm{Hg} / \mathrm{Hg}_{2} \mathrm{SO}_{4}, \mathrm{Cu}$ was oxidized to $\mathrm{Cu}^{+}$and $\mathrm{Cu}^{+}$reacted with dca in solution to form $\mathrm{Cu}(\mathrm{I}) \mathrm{dca}$. But some formation of $\mathrm{Cu}^{2+}$ is not excluded and $\mathrm{Cu}^{2+}$ can also react with dca anions to form $\mathrm{Cu}(\mathrm{II}) \mathrm{dca}$.

The electrosynthesis was performed in the air atmosphere and this may affect the stability of $\mathrm{Cu}(\mathrm{I})$. To preferentially favor the formation of Cudca, electrolyses were performed during a shorter time $(6 \mathrm{~h})$ and under $\mathrm{N}_{2}$ atmosphere. The film was electrosynthesized on a copper plate substrate totally immersed in the solution by applying a potential of $0 \mathrm{~V}$ vs $\mathrm{Hg} / \mathrm{Hg}_{2} \mathrm{SO}_{4}$ during $6 \mathrm{~h}$. Surprisingly one could observe two regions on the substrate, one covered with a thin film and the other with a thicker film. The X-ray diffraction patterns characteristic of 2 regions are compared with the data for $\mathrm{Cu}(\mathrm{I}) \mathrm{dca}$ and $\mathrm{Cu}(\mathrm{II}) \mathrm{dca}$ synthesized by the chemical method in Fig. 8. The thin film was analyzed by two methods: Bragg Brantano and Grazing incidence $\left(2^{\circ}\right)$. Only characteristic peaks of
Cu(I)dca $\left(11.7^{\circ} ; 29.2^{\circ}\right.$ and $\left.31.5^{\circ}\right)$ are observed. The data relative to the thicker film present the characteristic peaks of $\mathrm{Cu}(\mathrm{I}) \mathrm{dca}\left(11.7^{\circ} ; 23.4^{\circ}\right.$ and peaks around $30^{\circ}$ ) and of $\mathrm{Cu}(\mathrm{II}) \mathrm{dca}\left(12.6^{\circ}\right.$ and $\left.14.2^{\circ}\right)$. So under $\mathrm{N}_{2}$ atmosphere the formation of $\mathrm{Cu}(\mathrm{II})$ dca for a long time is also detected together with $\mathrm{Cu}(\mathrm{I}) \mathrm{dca}$.

Experiments were also carried out with a duration of electrolysis at 0 $\mathrm{V}$ vs $\mathrm{Hg} / \mathrm{Hg}_{2} \mathrm{SO}_{4}$ decreased to $240 \mathrm{~s}$. The X-ray diffraction pattern of the film reveals only the characteristic peaks of $\mathrm{Cu}(\mathrm{I}) \mathrm{dca}$ observed at $11.7^{\circ}$ and around $30^{\circ}$.

Electrolysis were also performed at more positive potentials to investigate the effect of the applied potential on the film composition. The X-ray analysis of the obtained films with an applied potential of 0.3 $\mathrm{V}$ vs $\mathrm{Hg} / \mathrm{Hg}_{2} \mathrm{SO}_{4}$ for $1.5 \mathrm{~h}$ with $Q=57.94 \mathrm{C}$ and $1 \mathrm{~V}$ vs $\mathrm{Hg} / \mathrm{Hg}_{2} \mathrm{SO}_{4}(Q=$ $100 \mathrm{C}$ ) respectively indicates that both characteristic peaks of $\mathrm{Cu}(\mathrm{II}) \mathrm{dca}$ and $\mathrm{Cu}(\mathrm{I}) \mathrm{dca}$ are present. It can thus be concluded that the electrochemical formation of $\mathrm{Cu}(\mathrm{II}) \mathrm{dca}$ involves a step where the intermediate $\mathrm{Cu}(\mathrm{I})$ also react with dca to produce $\mathrm{Cu}(\mathrm{I}) \mathrm{dca}$. A powder obtained in solution by potentiostatic electrolyse performed at $1 \mathrm{~V} / \mathrm{Hg} / \mathrm{Hg}_{2} \mathrm{SO}_{4}$ at a $\mathrm{Cu}$ electrode in presence of $0.05 \mathrm{M} \mathrm{NaNO}_{3}+0.05 \mathrm{M}$ Nadca methanolic solution under $\mathrm{N}_{2}$ atmosphere was made essentially of $\mathrm{Cu}(\mathrm{II})$ dca and its adsorption properties were evaluated.

\subsection{Specific surface area and adsorption capacities}

The adsorption properties were investigated on the powder made of $\mathrm{Cu}$ (II)dca obtained by potentiostatic electrolyses performed at $1 \mathrm{~V} / \mathrm{Hg}$ / $\mathrm{Hg}_{2} \mathrm{SO}_{4}$ at a $\mathrm{Cu}$ electrode in presence of $0.05 \mathrm{M} \mathrm{NaNO}_{3}+0.05 \mathrm{M}$ Nadca methanolic solution under $\mathrm{N}_{2}$ atmosphere. 

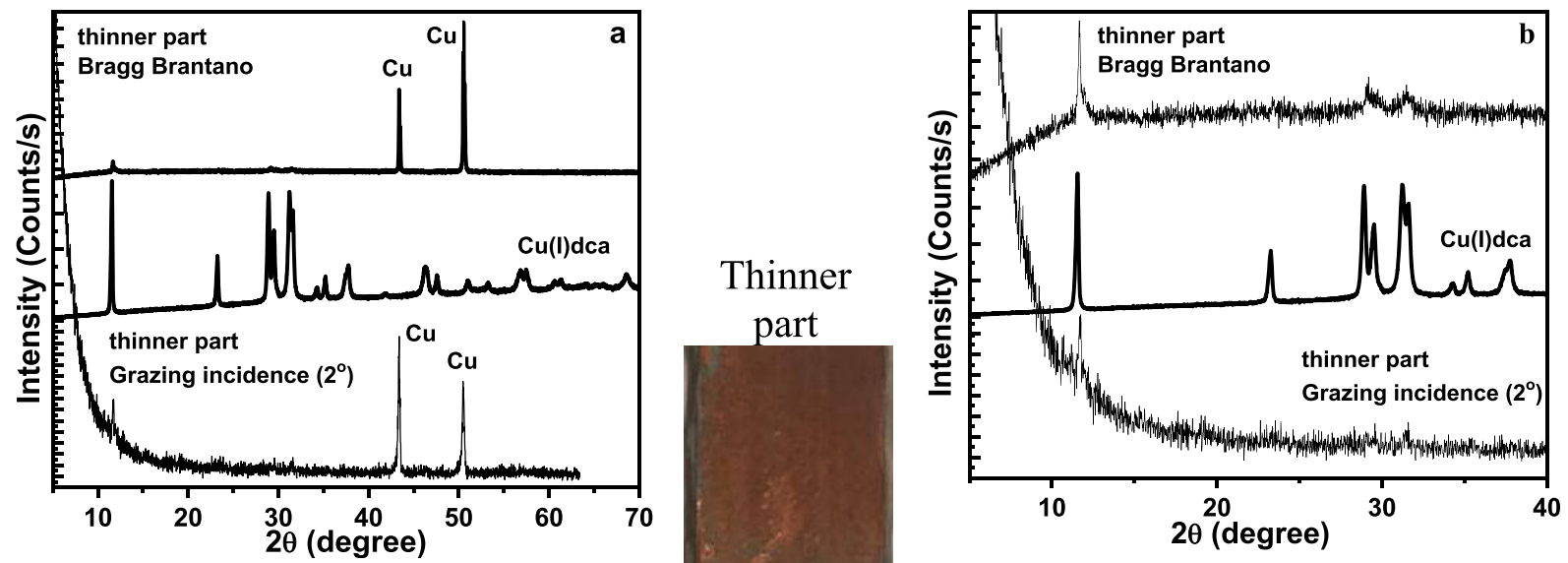

Thicker

part

d
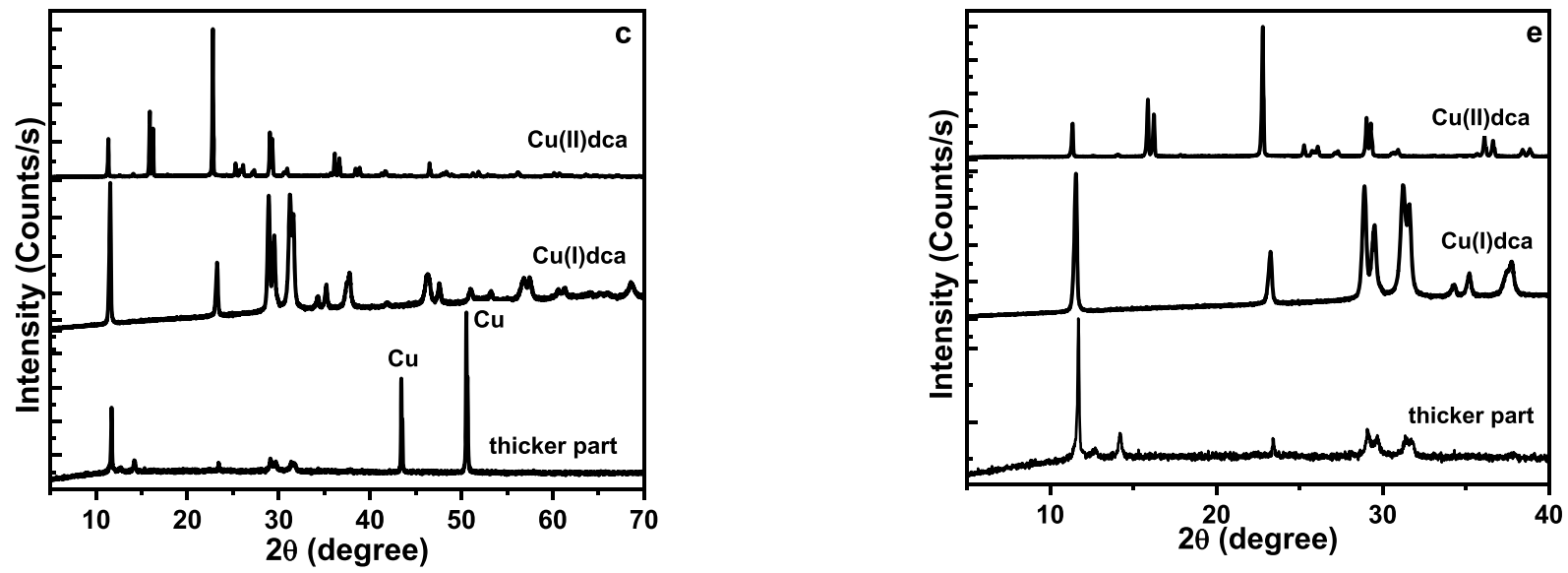

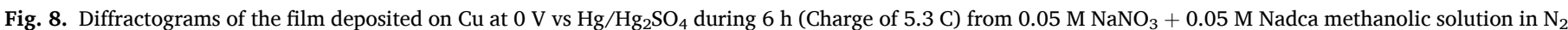

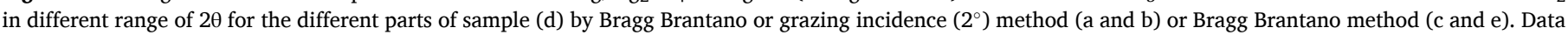
for $\mathrm{Cu}(\mathrm{I}) \mathrm{dca}$ and $\mathrm{Cu}(\mathrm{II})$ dca obtained chemically are given for comparison.
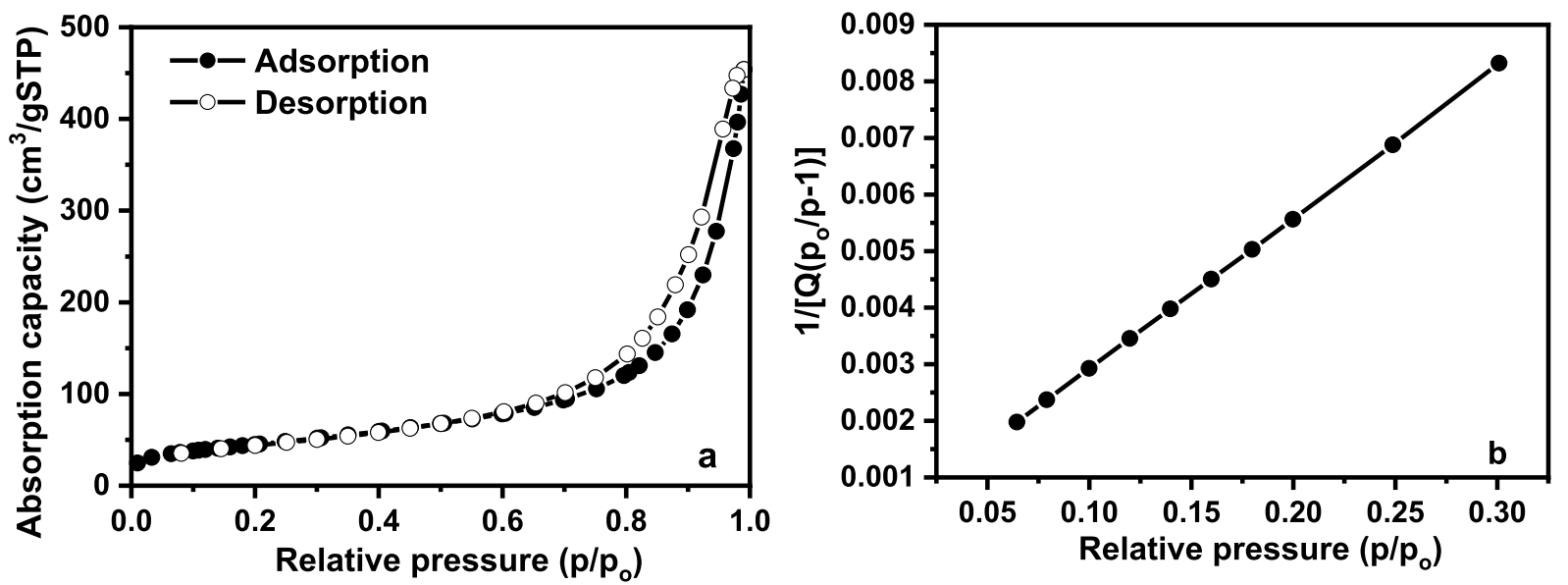

Fig. 9. (a), Isotherm plot of the electrosynthesized $\mathrm{Cu}(\mathrm{II}) \mathrm{dca}$ powder at $22{ }^{\circ} \mathrm{C}$ and (b) the corresponding BET surface area plot. 


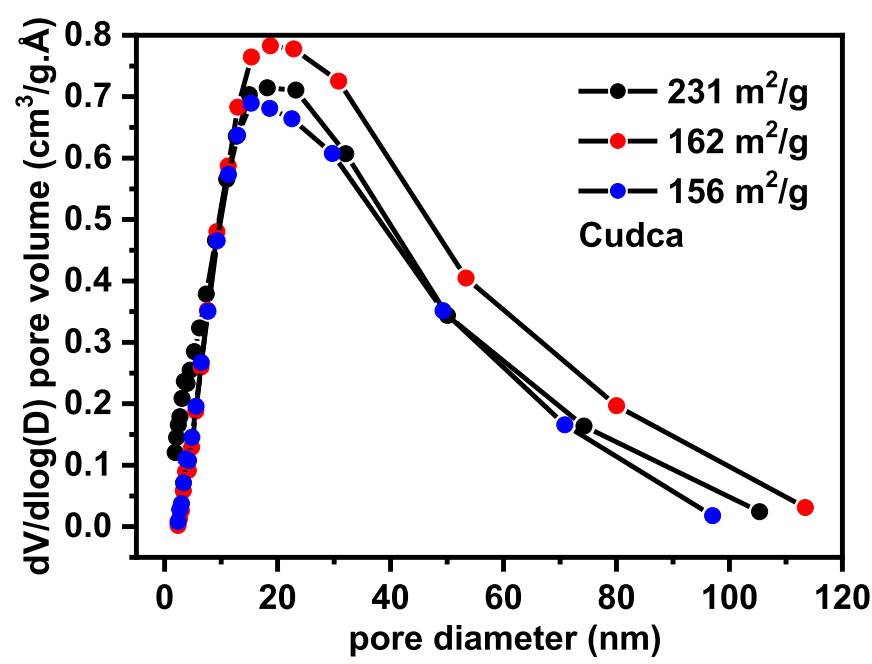

Fig. 10. Distribution of pore size of different samples of electrosynthesized Cu (II)dca.

The thermal behavior of the powder synthesized at $1 \mathrm{~V}$ vs $\mathrm{Hg}$ / $\mathrm{Hg}_{2} \mathrm{SO}_{4}$ in the methanolic solution containing $0.05 \mathrm{M} \mathrm{NaNO}_{3}$ and $0.05 \mathrm{M}$ Nadca was investigated by TGA analysis. From $50^{\circ} \mathrm{C}$ to $100^{\circ} \mathrm{C}$, a loss of absorbed water is observed. Above $180^{\circ} \mathrm{C}$, the structure of the materials falls in.

Brunauer - Emmett - Teller (BET) measurements and adsorption experiments involving dyes (methylene blue, methyl orange and Congo red) and gasses $\left(\mathrm{CO}\right.$ and $\mathrm{CO}_{2}$ ) have been carried to evaluate their specific surface area, pore characteristics and adsorption abilities.

Fig. 9a presents the $\mathrm{N}_{2}$ isotherm plot of a powder synthesized in the presence of Nadca after transfer of $100 \mathrm{C}$ at a $1 \mathrm{~cm}^{2} \mathrm{Cu}$ electrode at $1 \mathrm{~V}$. The specific surface area was determined from the BET surface area plot (Fig. 9b). The specific surface area determined for different samples prepared in the same conditions following the BET model is: $(183 \pm 59)$ $\mathrm{m}^{2} / \mathrm{g}$. The pore volume and average pore size extracted from the data is $(0.72 \pm 0.05) \mathrm{cm}^{3} / \mathrm{g}$ and $(15 \pm 2) \mathrm{nm}$ (Fig. 10). Experiments on powders synthesized at $1 \mathrm{~V}$ vs $\mathrm{Hg} / \mathrm{Hg}_{2} \mathrm{SO}_{4}$ from a larger $\mathrm{Cu}$ surface $\left(3 \mathrm{~cm}^{2}\right)$ and $300 \mathrm{C}$ transferred give similar results with a specific surface area of (145 $\pm 73) \mathrm{m}^{2} / \mathrm{g}$.

\section{Adsorption capacities}

The adsorption capacities have been evaluated for powders obtained by electrolysis at $1 \mathrm{~V}$ after $100 \mathrm{C}$ transferred at a $1 \mathrm{~cm}^{2} \mathrm{Cu}$ electrode. Adsorption measurements on the electrosynthesized $\mathrm{Cu}(\mathrm{II}) \mathrm{dca}$ powders were carried out in batches containing methylene blue, methyl orange or Congo red respectively, according to the procedure described in the experimental section. After separation by centrifugation of the adsorbent, the dye solution was analyzed by spectrophotometry. Fig. 11 shows the absorbance of the solutions of methylene blue, methyl orange and Congo red respectively after contact with the Cudca powder during a controlled time.

In contrast to the methylene blue solution where the absorbance is not significantly modified after contact with the $\mathrm{Cu}(\mathrm{II}) \mathrm{dca}$ powder, one observes a marked decrease of the absorbance of the methyl orange and Congo red solutions after $10 \mathrm{~min}$ of contact time with the adsorbent. Table 1 presents the amount of the dye adsorbed $\mathrm{Q}(\mathrm{mg} / \mathrm{g})$ and the corresponding extraction yield $\mathrm{H}(\%)$.

Longer contact times of the powder with the methylene blue solution do not significantly modify the amount adsorbed (after $15 \mathrm{~h}$ the yield is only of $1.5 \%$ ). By increasing the contact times of the powder with the two other solutions a slight increase in the adsorbent yield is still observed: $95 \%$ adsorption yield after $20 \mathrm{~min}$ for methyl orange and $97 \%$ after $30 \mathrm{~min}$ for Congo red.

Although the specific surface area is not very high, $\mathrm{Cu}(\mathrm{II}) \mathrm{dca}$ can adsorb methyl orange and Congo red, both anionic dyes, with high extraction yields while it adsorbs only little the cationic methylene blue. This indicates that electrostatic interactions dominate the adsorption process and suggest that $\mathrm{Cu}(\mathrm{II}) \mathrm{dca}$ has a high isoelectric $\mathrm{pH}$ that confers a positive charge to the adsorbent in water.

Compare with other materials, a multilamellar mesoporous $\mathrm{TiO}_{2} /$ ZSM-5 $\left(1151 \mathrm{~m}^{2} / \mathrm{g}\right)$ was used as photo-catalytic degradation of methyl orange dye, under $180 \mathrm{~min}$, methyl orange dye was efficiently decolorized and mineralized to 99.55 and $99 \%$, respectively, at an initial methyl orange concentration of $20 \mathrm{mg} / \mathrm{L}$ [23]. Biodegradable natural carbohydrate polymeric adsorbents of rice flour and graham flour used for methyl orange adsorption showed a maximum adsorption of 173.24 and $151.27 \mathrm{mg} / \mathrm{g}$, respectively [24]. The natural polymers such as wheat flour, turmeric powder, pure starch, starch nanoparticles, and some other forms of rice or wheat grains, while synthetic polymeric adsorbents were polyaniline (PAni) and PAni/starch composites were systematically studied for the adsorption of methylene blue and orange

Table 1

Adsorption capacity (Q) and extraction yield (H) of Cu(II)dca in presence of different dyes (after $10 \mathrm{~min}$ ).

\begin{tabular}{lll} 
& $\mathrm{Q}(\mathrm{mg} / \mathrm{g})$ & $\mathrm{H}(\%)$ \\
Methylene blue & 0.15 & 0.4 \\
Methyl orange & 33 & 87 \\
Congo red & 30 & 81 \\
\hline
\end{tabular}

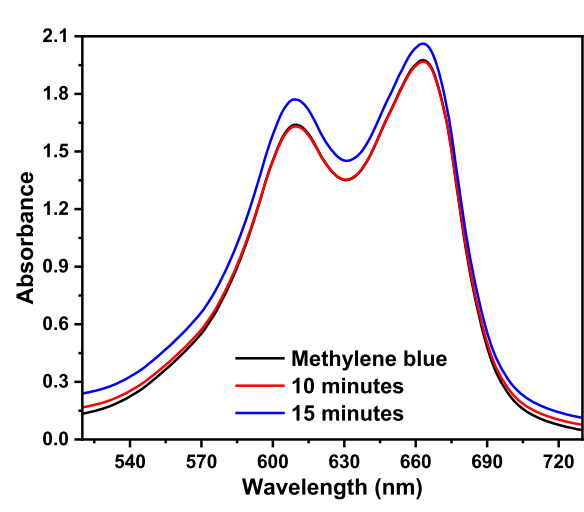

a

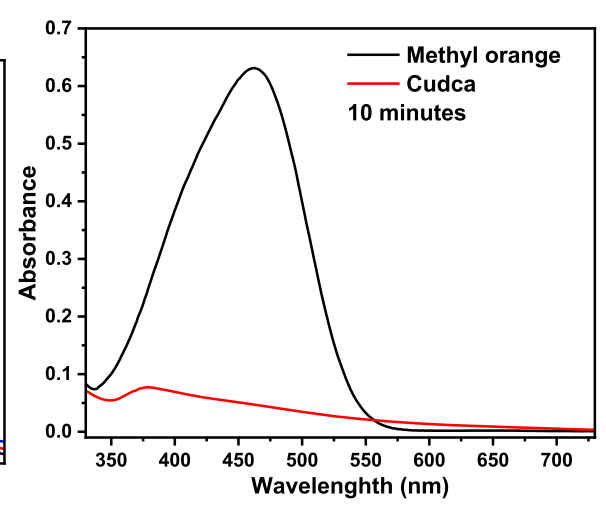

b

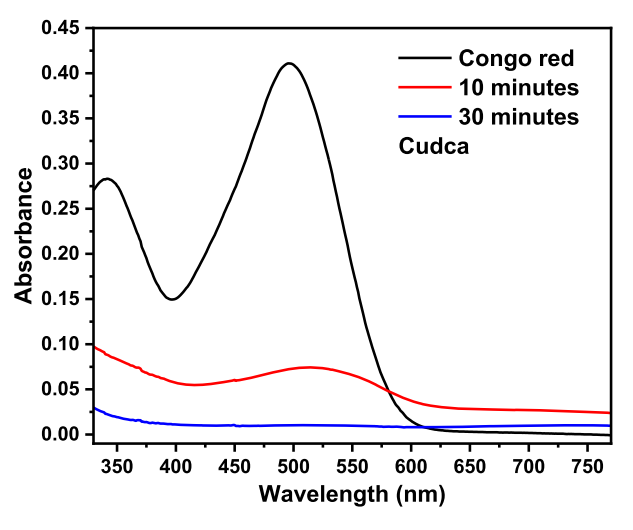

C

Fig. 11. Absorbance of the solution of adsorption methylene blue (a), methyl orange (b) and Congo red (c) after adsorption at the Cu(II)dca powder as a function of the wavelength. Contact times of the adsorbent with the solution as indicated. 
green. The cost for treatment of $1000 \mathrm{~L}$ wastewater is cheapest with the use of wheat flour and the most expensive in the case of PAni [25].

The capacity of $\mathrm{CO}_{2}$ and $\mathrm{CO}$ adsorption by $\mathrm{Cu}(\mathrm{II}) \mathrm{dca}$ was also investigated following the procedure described in the experimental section. Analysis of the data obtained with measurements performed on different samples prepared in the same conditions based on the comparison with a $\mathrm{SiC}$ sample as reference material gives $(1.02 \pm 0.07)$ $\mathrm{mmol} / \mathrm{g}$ and $(0.88 \pm 015) \mathrm{mmol} / \mathrm{g}$ for the adsorption of $\mathrm{CO}_{2}$ and $\mathrm{CO}$ respectively. $\mathrm{Cu}(\mathrm{II}) \mathrm{dca}$ can thus adsorb $\mathrm{CO}_{2}$ and $\mathrm{CO}$ and the capacity for $\mathrm{CO}_{2}$ is somewhat higher than for $\mathrm{CO}$.

\section{Conclusions}

An insoluble $\mathrm{Cu}(\mathrm{I}) \mathrm{dca}$ film can be synthesized on a gold or copper electrode by the reduction of $\mathrm{Cu}(\mathrm{II})$ or oxidation of $\mathrm{Cu}(0)$ in aqueous or methanolic solution containing dicyanamide ions. By resorting to the use of the ruthenium hexaammine redox probe the $\mathrm{Cu}(\mathrm{I}) \mathrm{dca}$ film was shown to be electronically conductive although the deposition rate decreases when the film formation proceeds. Depending on the applied potential, not only $\mathrm{Cu}(\mathrm{I}) \mathrm{dca}$ but also $\mathrm{Cu}(\mathrm{II}) \mathrm{dca}$ can also be formed. The powder obtained by electrolysis at $1 \mathrm{~V}$ vs $\mathrm{Hg} / \mathrm{Hg}_{2} \mathrm{SO}_{4}$ made essentially of $\mathrm{Cu}(\mathrm{II}) \mathrm{dca}$ presents a specific surface area of $(183 \pm 59) \mathrm{m}^{2} / \mathrm{g}$. This material can adsorb preferentially methyl orange and Congo red dyes compare to methylene blue whereas no marked difference is obtained between $\mathrm{CO}$ and $\mathrm{CO}_{2}$ adsorption. Compare with other materials, although with a not very high specific surface area, $\mathrm{Cu}(\mathrm{II}) \mathrm{dca}$ powders are potential adsorbents for dyes and gas.

\section{CRediT authorship contribution statement}

Phuong Thu Nguyen: Investigation, Formal analysis, Project administration, Writing - original draft, Writing - review \& editing. Thom Thi Nguyen: . Nam Thi Pham: . Claudine Buess-Herman: Methodology, Supervision, Project administration, Writing - review \& editing. Hien Thi Le Nguyen: . Thanh Thi Mai Dinh: Supervision, Project administration, Writing - review \& editing.

\section{Declaration of Competing Interest}

The authors declare that they have no known competing financial interests or personal relationships that could have appeared to influence the work reported in this paper.

The authors declare that they have no conflicts of interest.

\section{Acknowledgments}

This research was funded by the Institute for Tropical Technology (ITT), Vietnam Academy of Science and Technology (VAST) and the Commission Universitaire au Développement (CUD) within the framework of the project between Université libre de Bruxelles (ULB) and ITT, VAST. The authors thanks Prof. T. Doneux (ULB) for fruitful discussions and Prof. T. Visart for making the equipment for gas adsorption measurements available for this work.

\section{References}

[1] S.R. Batten, P. Jensen, B. Moubaraki, K.S. Murray, R. Robson, Structure and molecular magnetism of the rutile-related compounds $\mathrm{M}(\mathrm{dca})_{2}, \mathrm{M}=\mathrm{Co}^{\mathrm{II}}, \mathrm{Ni}^{\mathrm{II}}, \mathrm{Cu}^{\mathrm{II}}$, dca = dicyanamide, $\mathrm{N}(\mathrm{CN})_{2}{ }^{-}$, Chem. Commun. (1998) 439-440.
[2] M. Kurmoo, C.J. Kepert, Hard magnets based on transition metal complexes with the dicyanamide anion, $\left\{\mathrm{N}(\mathrm{CN})_{2}\right\}$, New J. Chem. 22 (1998) 1515-1524.

[3] Y.J. Shi, X.T. Chen, Y.Z. Li, Z. Xue, X.Z. You, Pb(dca) $)_{2}$ (dca = dicyanamide): a novel 3D compound with unusual coordination modes of dicyanamide, New J. Chem. 26 (2002) 1711-1713.

[4] D.O. Demchenko, A.Y. Liu, E.Z. Kurmaev, L.D. Finkelstein, V.R. Galakhov, A. Moewes, S.G. Chiuzbaian, M. Neumann, C.R. Kmety, K.L. Stevenson, Electronic structure of transition-metal dicyanamides $\mathrm{Me}\left[\mathrm{N}(\mathrm{CN})_{2}\right]_{2}(\mathrm{Me}=\mathrm{Mn}, \mathrm{Fe}, \mathrm{Co}, \mathrm{Ni}$, Cu), Phys. Rev. B 69 (2004) 205105-205113.

[5] M. Biswas, G.M. Rosair, G. Pilet, S. Mitra, Syntheses, structures and magnetic properties of $\left[\mathrm{M}^{\mathrm{II}}(\mathrm{dca})_{2}\left(\mathrm{CH}_{3} \mathrm{OH}\right)_{2}\right] \mathrm{n}$, where $\mathrm{M}=\mathrm{Co}$ or $\mathrm{Cu}$ and dca ${ }^{-}=$dicyanamide, $\mathrm{N}(\mathrm{CN})_{2}$, Inorganica Chim. Acta 360 (2007) 695-699.

[6] T. Tüken, F. Demir, N. Kıcır, G. Sığrcık, M. Erbil, Inhibition effect of 1-ethyl-3methylimidazolium dicyanamide against steel corrosion, Corros. Sci. 59 (2012) $110-118$.

[7] M. Xu, D.G. Ivey, W. Qu, Z. Xie, Study of the mechanism for electrodeposition of dendrite-free zinc in an alkaline electrolyte modified with 1-ethyl-3-methylimidazolium dicyanamide, J. Power Sources 274 (2015) 1249-1253.

[8] F.A. Mautner, C.N. Landry, A.A. Gallo, S.S. Massoud, Molecular structure of mononuclear azido-and dicyanamido-Cu(II) complexes, J. Mol. Struct. 837 (2007) $72-78$.

[9] H. Hadadzadeh, A.R. Rezvani, H. Esfandiari, Dinuclear copper complexes with cyanamide derivatives as bridging ligands, Polyhedron 27 (2008) 1809-1817.

[10] T. Chattopadhyay, A. Banerjee, K.S. Banu, N. Podder, M. Mukherjee, M. Ghosh, E. Suresh, D. Das, Ligand effect on the growth reaction of copper(II) dicyanamide complexes: syntheses, characterization and X-ray single crystal structure analyses of $\left[\mathrm{CuL}\left\{\mathrm{N}(\mathrm{CN})_{2}\right\}_{2}\right]_{\mathrm{n}}$ and [CuL' $\left.\left\{\mathrm{N}(\mathrm{CN})_{2}\right\}_{2}\right]_{2}\left[\mathrm{~L}=2\right.$-(aminoethyl)pyridine and $\mathrm{L}^{\prime}=$ 2-(aminomethyl)pyridine], J. Mol. Struc. 888 (2008) 62-69.

[11] F.A. Mautner, J.H. Albering, M. Mikuriya, S.S. Massoud, Dicyanamido-metal (II) complexes. Part 5: first example for an unit cell containing dinuclear and 1-D polymeric Cu(II) complexes bridging by dicyanamide, Inorg. Chem. Commun. 13 (2010) 796-799.

[12] S. Biswas, A. Ghosh, Structural variations in polynuclear copper(II) complexes based on salicylaldimine type ligands along with dicyanamido co-ligand, Polyhedron 39 (2012) 31-37.

[13] M. Fondo, A.M. García-Deibe, N. Ocampo, R. Vicente, J. Sanmartin, C. Sanudo, $\mathrm{Cu}_{2}{ }_{2}^{\mathrm{II}}$ based polymeric ladder using dicyanamide bridges: synthesis, crystal structure and magnetic studies, Inorganica Chimi. Acta 373 (2011) 73-78.

[14] S.R. Batten, A.R. Harris, P. Jensen, K.S. Murray, A. Ziebell, Copper(I) dicyanamide coordination polymers: ladders, sheets, layers, diamond-like networks and unusual interpenetration, J. Chem. Soc., Dalton Trans. (2000) 3829-3835.

[15] A. Tekin, O. Karalti, F. Karadas, A metal dicyanamide cluster with high $\mathrm{CO}_{2} / \mathrm{N}_{2}$ selectivity, Micropor. Mesopor. Mat. 228 (2016) 153-157.

[16] J.L. Manson, C.D. Incarvito, A.L. Rheingold, J.S. Miller, Structure and magnetic properties of $\mathrm{Mn}^{\mathrm{II}}\left[\mathrm{N}(\mathrm{CN})_{2}\right]_{2}$ (pyrazine). An antiferromagnet with an interpenetrating 3-D network structure, J. Chem. Soc., Dalton Trans. (1998) 3705-3706.

[17] J.L. Manson, C.R. Kmety-Stevenson, Q. Huang, J.W. Lynn, G.M. Bendele, S. Pagola, P.W. Stephens, L.M. Liable-Sands, A.L. Rheingold, A.J. Epstein, J.S. Miller, Structure and Magnetic Ordering of $\mathrm{M}^{\mathrm{II}}\left[\mathrm{N}(\mathrm{CN})_{2}\right]_{2}(\mathrm{M}=\mathrm{Co}$, Ni), Chem. Mater 10 (1998) 2552-2560.

[18] D.R. MacFarlane, S.A. Forsyth, J. Golding, G.B. Deacon, Ionic liquids based on imidazolium, ammonium and pyrrolidinium salts of the dicyanamide anion, Green Chem 4 (2002) 444-448.

[19] S. Vanderaspoilden, J. Christophe, T. Doneux, C. Buess-Herman, Contrasted electrochemical behaviour of $\mathrm{Cu}(\mathrm{I})$ and $\mathrm{Cu}(\mathrm{II})$ ions in 1-butyl-3-methylimidazolium dicyanamide, Electrochim. Acta 162 (2015) 156-162.

[20] Q. Rayée, Etude du comportement des ions $\mathrm{Cu}(\mathrm{II})$ et $\mathrm{Cu}(\mathrm{I})$ en présence d'anions dicyanamide à une électrode d'or, Master thesis, Université Libre de Bruxelles, Belgium, 2013.

[21] O. Reckeweg, R.E. Dinnebier, A. Schulz, B. Blaschkowski, C. Schneck, T. Schleid, About the air- and water-stable copper(I) dicyanamide: synthesis, crystal structure, vibrational spectra and DSC/TG analysis of $\mathrm{Cu}\left[\mathrm{N}(\mathrm{CN})_{2}\right]$, Z. Naturforsch. B: J. Chem. Sci. 72 (2017) 159-165.

[22] Quentin Rayée, Phuong Thu Nguyen, Tiriana Segato, Marie-Paule DelplanckeOgletree, Thomas Doneux, Claudine Buess-Herman, Electrochemical synthesis of copper(I) dicyanamide thin films, J. Electroanal. Chem. 819 (2018) 331-337.

[23] Hussein Znad, Khalid Abbas, Sufia Hena, Rabidul Awual, Synthesis a novel multilamellar mesoporous $\mathrm{TiO}_{2}$ /ZSM-5 for photo-catalytic degradation of methyl orange dye in aqueous media, J. Environ. Chem. Eng. 6 (2018) 218-227.

[24] Md.Munjur Hasan, Md.Nazmul Hasan, Md.Rabiul Awual, Md.Mominul Islam, M. A. Shenashen, Jibran Iqbal, Biodegradable natural carbohydrate polymeric sustainable adsorbents for efficient toxic dye removal from wastewater, J. Mol. Liq. 319 (2020), 114356.

[25] Md.Bin Yeamin, Md.Mominul Islam, Al-Nakib Chowdhury, Rabiul Awual, Efficient encapsulation of toxic dyes from wastewater using several biodegradable natural polymers and their composites, J. Clean. Prod. 291 (2021), 125920. 